\title{
AN EXPOSITION OF THE SOCIO-ECONOMIC IMPACTS OF CONSTRUCTION SITE ACCIDENTS IN NIGERIA
}

\author{
Okorie $^{1}$, VN; Adindu ${ }^{2}$, CC \\ ${ }^{1}$ Department of Quantity Surveying, University of Benin, Edo State, Nigeria \\ ${ }^{2}$ Department of Project Management Technology, Federal University of Technology, Minna, \\ Niger State, Nigeria \\ E-mail:*v.okorie@yahoo.com,victor.okorie@uniben.edu,chinedu.adindu@futminna.edu.ng.
}

\begin{abstract}
Nigeria's construction sector is a key to the development of national economy, especially its contribution to employment creation and value addition to the national gross domestic product. The mode of workforce recruitment, job retention and disengagement are largely informal with an attendant high rate of construction site accidents often resulting in injuries and fatalities to persons and properties. This study examines the social and economic effects of site accidents on Nigerian economy. Descriptive survey research was employed with structured questionnaire as research design and administered to twenty major construction companies operating within southern Nigeria. Interviews were also conducted with owners/directors, contract managers, construction project managers, health and safety officers, site managers, affected workers and families alike to validate study results. Data obtained from field survey were analyzed. The study revealed loss of company productivity, reduction in living standards as having the most economic impacts on construction companies and their affected workers/families respectively. Additionally, loss of customers' confidence and loss of the family bread winner represents the highest social impacts on the construction companies and affected workers/ families. The study concludes that there is existence of low commitment towards workers' health, safety and general wellbeing by Nigerian construction firms. The study therefore, recommends that government at all levels should enact and strictly enforce Construction Industry Health and Safety Laws, and sanction firms that contravene Health and Safety Regulations. Furthermore, construction firms irrespective of size should demonstrate visible leadership towards workers' health and safety.
\end{abstract}

Keywords : Accident, construction industry, economic, health and safety, Nigeria

\section{INTRODUCTION}

A major criteria for designating a nation as developed or undeveloped is the safety of its human capital (Wikipedia, 2019). The high rate of reported and unreported incidences of workforce injuries and other casualties have placed the nations' construction sites on top in the league of dangerous work environments in Nigeria (Akinwale and Olusanya, 2016; Okorie and Musonda, 2018). Asanka and Ranasinghe (2015) assert that accidents constitute a main disadvantage of the construction industry. Risk of injuries and fatalities in construction is 7-10 times higher than other sectors of the national economy (International Labor Organization (ILO, 2010). Studies further show that the construction industry lags behind transportation industry in accident occurrence (National Occupational Safety and Information Centre (NOSHIC), 2006). The monetary cost of construction accidents is over $10 \%$ of the nations' gross domestic product (GDP) (ILO, 2010).

The industry within the 2010-2015 period, witnessed 360 accident casualties aside over 210,000 disabilities (Vanguard Newspaper, 2016). Furthermore, over 340,000 work days were lost arising from injuries to construction site workers (Fewings, 2010). According to Okoye, Okolie and Ngwu (2017), the financial effect of the losses is conservatively put at USD60 billion. Thus, the low performance of construction industry in terms of health and safety practices is not locally situated, but globally attributed. This ugly incident is uncalled of considering the critical role of construction workforce in the industry's overall productivity performance. 
Globally, construction accident records and statistics reveal that not less than 60,000 fatal construction accidents occur yearly. Also, construction sites constitute about $16.67 \%$ of composite industrial workplace fatal accidents. Accidents on construction sites also constitute between $25 \%-40 \%$ of deaths in industrialized nations, despite construction industry's low share (6-10\%) of all industrial sectors (International Labour Organization, 2005).

Additional to the cost of manpower, the financial and social impacts of construction site accidents is mind-blowing (Oloke, 2010). Direct costs arising from cost of workmen injuries, illness, and damage to property and equipment are basically insurable, and are of a minor economic significance when compared to indirect cost of accidents (Hinze, 2006). Undoubtedly, low consciousness and abysmally poor commitment to construction health and safety values among Nigeria construction companies have unprecedented socio-economic implication on the nation economy. McAleenan (2010) posits that for every $£ 1$ expended on site accidents by insurance firms, contracting organizations expend $£ 100$ as attendant indirect costs.

According to Hinze (2006), indirect costs emanated from products and materials damage to legal costs. Nonetheless, both the direct and indirect costs of site accidents have negative impacts on companies and the society. For instance, site accidents have significant impact on national medical care services (Akinwale and Olusanya, 2016). In addition, young men and women who are the family bread winners are perhaps killed in construction sites leading to loss of workforce to the society. This could have long-term cyclical effects on the economy.

Site workers constitute formidable human capital and human resource capacity of construction companies (Lutchman, Maharaji and Ghanem, 2012). Therefore, health, safety and wellbeing of Nigerian construction site workers should be a priority to the government and contracting companies. The ILO (2010) maintains that no price paid in form of compensation for human life can be enough. The negative economic and social impacts resulting from site accidents in Nigeria are enormous and should be prevented.

While research abound on the causes of construction site accidents in Nigeria; the economic and social implications of construction site accidents have in the contrary, received a scanty attention by researchers. This paper therefore, seeks to fill-in the gap by examining construction accidents and their socio-economic impacts on the Nigerian society.

\section{LITERATURE REVIEW}

\subsection{Causes of construction site accidents}

A typical construction site is beclouded with risks of sorts. Goetsch (2014) states that in construction sites, workers are often handed over a somewhat regimented production pattern characterized with fixed input schedule, unrealistic production deadlines with little or no production guidelines. Goetsch (2014) further states that the work requirement often contains very minimal specifications and technical criteria that are most times ill- conceived by the project stakeholders. There is also an unavailability of comprehensive safe working manuals to ensure accident free construction operations (Hinze, 2006).

Based on the above findings, construction accidents do not just happen, but are cause mainly as a result of lack of safety consciousness (Fewings, 2010). Hughes and Ferrett (2010) identified some acts inimical to safety consciousness such as deliberate indulgence on unsafe acts, use of improper work tools, leaving an open hole unguarded, not wearing appropriate safety gadgets, and taking-off a material from a machine while in motion. Hinze (2006) posits that unsafe acts, and or unsafe conditions constitute about $87 \%$ of all construction site accidents. The unsafe acts are violations of accepted safe procedures of work, while unsafe conditions are the existence of hazardous physical conditions in the working environment (Gambatese, 2008). Conchie, Taylor and Charlton (2011) argue that most accidents result from a combination of contributing causes. Notably, accidents occur due to failure of control by management. Therefore, all forms of accidents can be prevented through concerted efforts of government, contracting firms and workers. Flin and Yule (2003) and Goetsch (2014) declare that accidents occur as a result of low concern of management of construction organisations towards the health and safety of construction site workers. Some factors that lead to construction site accidents have been identified by the following researchers, namely: Musonda, Pretorius and Haupt (2012) poor H\&S training of workers, Hughes 
and Ferrett (2010) inadequate financial provision for H\&S, Lutchman et al. ( 2012) poor H\&S culture and Wu and Fang (2012) lack of top management commitment to H\&S.

In spite of the above identified and several other causative agents of construction site accidents, the lack of a structured H\&S training of site workforce is key, as regular education and training helps in creating necessary awareness about hazards and risks associated with specific construction operations and environment (Musonda et al. 2012; Lutchman et al. 2012). Compared to the developed countries, regrettably, many contractors of developing economies like Nigeria hardly invest in training of construction site workers as they often consider such as a luxury and an avoidable expenditure (Okorie and Aigbovboa, 2016).

Poor H\&S training of site workers has worldwide been noted as a major concern begging for improvement in the construction industry (WHO, 2010). Practices that emphasize and encourage a safe working culture is not only profitable but also enhances an organisations' corporate image, and this is remarkable too (ILO, 2011). Similarly, apart from satisfying legal and moral obligations, H\&S training has the potential to change workers' H\&S behaviour for better.

Inadequacy of funding has also been identified as a major factor militating against an efficient and effective management of health and safety in Nigeria construction sites. Poor allocation of funds to Health and Safety aspects at both pretender and pre-contract stages of a proposed contract, by clients and their design team also impact negatively on contractors' site H\&S performance (Olatunji, Sher and Gu, 2011). Lack of budgeting and adequate funding of $\mathrm{H} \& \mathrm{~S}$ activities especially at the conceptual planning stages of projects often result in construction site accidents and other fatalities. Early appointment of a professional quantity surveyor on a construction project would help ensure an adequate budgeting and allotment of funds for project's H \& S practices, by ensuring their specific provision in the contract documents. Olatunji et al. (2011) avers that such a provision would go a long way in reducing most H\&S challenges encountered on construction sites in the course of a project execution.

ILO (2011) reports that construction accidents would continue to occur despite efforts of government and trade unions, unless construction companies show improved zeal and upscale their present tempo of commitment with regards to the $\mathrm{H} \& \mathrm{~S}$ of their site workforce. Construction site workers are humans, as such, their health, safety and wellbeing should be a priority to the management of organisations in order to maintain uninterrupted workflow and productivity in operations. According to Kheni (2008), organisations with a sound H\&S culture, have in their employ, workers with positive attitude towards $\mathrm{H} \& \mathrm{~S}$.

\subsection{Economic impacts of site accidents on company and society}

The cost implications of site accidents are frequently cited as a major motivation for addressing construction H\&S (Hinze, 2006). Hinze (2006) further describes construction accidents as the cancer of construction. According to the WHO (2010), over 1.25 trillion US dollars is spent annually on direct and indirect costs resulting from unsafe practices and unhealthy working conditions. International Labor Organization (ILO, 2011) puts global estimates of direct and indirect costs for accidents at USD 2.8 trillion. This is approximately $4 \%$ of global annual GDP (Leigh, 2011).

Construction companies and the larger society often bear the huge amount of money spent on occurrence of site accidents. Site accidents exert considerable economic pressure on both project stakeholders and the society at large. Okoye et al. (2017) assert that construction site accidents affect the bottom line of economic projections of construction businesses with particular emphasis on their profitability. Okoye et al. (2017) further identified some socio-economic effects of construction site accidents to include: the payment of additional preliminary costs and overhead charges in projects as a result of delays. Other expenses include cost incurred in the evacuation of spoils or debris together with the reconstruction of damaged works. In similar manner, Akinwale and Olusanya (2016) identified other socio-economic cost of construction site accidents as: high premium paid on insurance policy, payment of liquidated and ascertained damages to the client for delayed project completion; additional cost of capital for remedying damaged portions of work duly completed.

Notably, construction site accidents have also rendered many families financially and emotionally challenged as many wives and husbands have been decimated to a status of widows and widowers. In addition of being a widow or a widower the children of the affected families suffered most as they may drop out of school because of 
financial difficulties to pay for their education (WHO, 2010). Research conducted in South Africa by Mthalane, Othman and Pearl (2009) concluded that site accidents could cause a serious depression among families when they lost their bread winner. Death or injury of a family bread winner cannot be compensated with any monetary terms. Mthalane et al. (2009) further stated that construction site accidents have caused dearth of skilled and unskilled workers to the society. This has a direct impact on the nation's workforce.

Cost of treatment and other compensations paid to an injured worker constitute direct costs to the construction companies (Hinze, 2006), and while indirect costs are those costs that are borne by contractors through: loss of operational man-hours, workplace environmental sanitation costs, damage remediation costs, movement and transportation expenses, and numerous logistic support cost of affected workforce (Brauer, 2006). The economic impacts of both the direct and indirect cost of accidents to construction companies affects their profit margins, which, in turn, indirectly impacts on the national economy.

According to the WHO (2010) reports on safe-work, the medical expenses incurred by developing countries annually due to poor site H\&S management are over USD1000 billion. Regrettably, this enormous amount could have been used for other infrastructural development in the areas. Thus, the overall economic impacts of construction site accidents and ill health to the society are very huge and unacceptable. Generally, the cost of construction accidents and cost of treatment to workers' ill-health is in the range of $7 \%-10 \%$ of a country's gross national product (ILO, 2011). It is somewhat difficult and often an arduous task to objectively determine the economic consequence and financial implications of construction site accidents on construction companies and society, owing to numerous and often incalculable indirect costs aside very glaring direct costs.

\subsection{Social impacts of site accidents on company and society}

Construction site accidents have social impacts on contractors, workers and the community. For example, loss of reputation and erosion of public confidence (Goetsch, 2014), difficulty and higher cost of hiring labour and equipment as a result of high accident wastage levels (Fewings, 2010), high cost of litigations and claims settlement arising from adverse court verdicts (Huhes and Ferrett, 2010). Spangenberg (2009) points out that some site fatalities have the potential to cause a serious crisis within a construction company and sometimes permanent closure due to adverse publicity from the media. The adverse publicity by the media could lead to loss of confidence among the public which has social impacts on the affected company. In addition, serious site accidents can also cause psychological stress among top management, line managers, and workers leading to low morale of both management and workers. Furthermore, Okoye et al.(2017) maintain that site fatalities create tensions within the construction companies that are usually characterized with accusations and blames which may divert energies and resources away from the construction tasks at hand to accidents investigations. Consequently, the intangible costs arising from site accidents have attendant social impacts on contractors in the form of low morale of workers, lack of public confidence and tarnished image.

Families that lost their bread winner go through a state of shocks and overwhelmed with emotions (Mthalane et al. 2009). The affected families are devastated and completely depressed for losing the family provider. The social impacts of site accidents to the affected family and society are enormous. According to Mthalane et al. (2009), there will be decrease in standard of living, increase in debts and decrease in family income. The above negative impacts of site accidents suggest more burden to the society. In addition, the children of the death or injured site workers may drop out of school and this has long negative effects on the society. Arguably, construction site accidents impact on society and construction companies in diverse ways. Accident is preventable, government of Nigeria at all levels and contracting companies should demonstrate commitment and visible leadership in all matters concerning workers' H\&S in order to reduce the negative socio-economic impacts of site accidents especially to both society and construction company.

\section{METHODOLOGY}

To achieve the objectives of this study, a rigorous research approach, involving critical review of relevant related literature, a structured questionnaire development and distribution to the population of interest, complimented with oral interviews were undertaken. The purpose of the literature review was to deepen enquiry and to have a broad 
view of different dimension of construction health and safety especially issues of construction site accidents and its economic and social impacts on companies and society at large.

In order to elicit the perception of the construction companies, developed questionnaires were administered to twenty purposively selected contractors registered with both the Nation's Corporate Affairs Commission (CAC) and the Federal Ministry of Works and Housing (FMW\&H) operating within the study area. The administration of structured questionnaires considered factors such as years of experience and line of responsibility. The construction companies comprise those currently with on- going projects within the SouthSouth Geopolitical of Nigeria .The South-South Geopolitical zone of Nigerian was chosen for this study because of ever on-going construction projects being undertaken by the oil and gas companies operating within the zone. Consequently, accident records are assumedly high with varying levels of fatalities and attendant socio-economic impacts on the construction companies, the families of affected workers, the state, and the nation at large.

One hundred (100) questionnaires were distributed among the twenty selected construction companies, and fifty-six (56) questionnaires were duly completed and returned for data analysis representing 56\%. Thus 56\% response rate achieved in this survey provides reasonable data for analysis (Leedy and Ormrod, 2010). Oral interviews were also conducted with five randomly selected companies among the twenty contracting firms. The oral interviews were conducted with the company Directors, senior managers, middle managers, and site supervisors. An interview is an interaction between two or more people to gain insight relative to problems (Leedy and Ormrod, 2010). The interviews assisted the researcher to understand the awareness and perceptions of respondents relative to economic and social impacts of site accidents on construction companies and the society. Finally, oral interviews were conducted with few selected families of affected workers of the above mentioned employee categories to validate the economic and social impacts of construction site accidents. The interview segment also helped to ensure that sample selection was free from bias of all sorts, thus enhancing data integrity, validity and reliability. However, the interviewees particularly the affected families were unwilling to divulge information somewhat to the sensitivity of the subject matter of enquiry. At the construction company's headquarters, and site levels, interviewees apparently wanted to protect corporate records; while the individual respondents were afraid of their confidentiality being compromised.

\subsection{Data analysis}

To enhance data integrity, validity and reliability, the researchers spent six Months in gathering data for the study. A 56\% majority response was obtained from owners/directors of various organisations surveyed. About $54 \%$ of responding firms had cognate working experience spanning over 10 years. Also, $34 \%$ of the respondents had construction industry related academic and professional qualifications. Responses on items of survey were measured on Likert's 5-point scale for ease of data analysis. Both descriptive and inferential statistics from the study were generated with the aid of Statistical Package for Social Sciences (SPSS-version 10.0). A high Cronbach alpha coefficient of 0.90 was achieved, thus attesting to the internal consistency and reliability of the survey questionnaire.

\section{RESULTS}

\subsection{Economic impacts of site accidents on the construction company}

The questionnaire examines the economic impacts of site accidents on construction companies and Nigerian society. Measurement scale for the study ranged between 1 (minor impact) to 5 (major impact). Table 1 reveals the extent to which stated construction accident variables impact on the economy of construction firms. The eleven (11) study variables had a Mean Score (MS) average of 3.29; this was well above the 3.00 MS value, implying that respondents perceive that the accident variables under study have economic impacts on the construction firms. Study's results also indicate that 'loss of company productivity, damage to plants/equipment' ranked highest among stated accident variable factors.

Study results from respondents corroborated with literature review which both Brauer (2006) and Hinze (2006) which stated that the aggregate costs of accidents have negative impacts on the bottom line or profitability of construction companies. Although costs of rescue plants and equipment and costs of reworks or corrective 
works ranked lowest in terms of their mean score (MS) values of 3.16 and 3.15 respectively as shown in Table 1, these factors also have negative economic impacts on construction companies.

Table 1: Economic impacts of site accidents on the construction company

\begin{tabular}{|c|c|c|c|c|c|c|c|c|}
\hline \multirow{3}{*}{ Statement of Accident Variable Factor } & \multirow{3}{*}{ 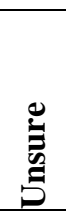 } & \multicolumn{5}{|c|}{ Response (\%) } & \multirow[b]{3}{*}{$\sum^{\infty}$} & \multirow{3}{*}{ 華 } \\
\hline & & \multicolumn{5}{|c|}{ Minor impact......... Major Impact } & & \\
\hline & & 1 & 2 & 3 & 4 & 5 & & \\
\hline Loss of company productivity & 4.2 & 6.3 & 11.9 & 25.2 & 29.4 & 23.1 & 3.51 & 1 \\
\hline Damage to plants and equipment & 9.1 & 4.9 & 9.8 & 27.9 & 27.9 & 20.3 & 3.49 & 2 \\
\hline $\begin{array}{l}\text { Payments for settlement of injury or death } \\
\text { claims }\end{array}$ & 7.7 & 5.6 & 14.7 & 23.1 & 28.7 & 20.3 & 3.43 & 3 \\
\hline $\begin{array}{l}\text { Training costs for replacement of injured } \\
\text { worker }\end{array}$ & 8.4 & 7.7 & 10.5 & 27.9 & 31.5 & 13.9 & 3.34 & 4 \\
\hline $\begin{array}{l}\text { Salaries and wages paid to injured while in } \\
\text { hospital }\end{array}$ & 6.3 & 5.6 & 11.9 & 40.6 & 12.7 & 13.9 & 3.27 & 5 \\
\hline $\begin{array}{l}\text { Slowdowns in operations during accidents } \\
\text { investigations }\end{array}$ & 5.6 & 9.1 & 12.6 & 29.4 & 32.2 & 11.2 & 3.24 & 6 \\
\hline Medical bills and expense & 7.0 & 9.9 & 16.9 & 26.1 & 24.7 & 15.5 & 3.23 & 7 \\
\hline Legal fees for defence against claims & 7.7 & 6.9 & 18.2 & 30.8 & 27.3 & 14.1 & 3.21 & 8 \\
\hline Increased insurance costs & 6.4 & 7.4 & 17.1 & 30.2 & 26.3 & 13.8 & 3.20 & 9 \\
\hline Costs of rescue plants and equipment & 7.4 & 6.8 & 16.3 & 27.2 & 25.7 & 13.2 & 3.16 & 10 \\
\hline Costs of reworks or corrective works & 8.3 & 7.1 & 15.6 & 27.1 & 23.1 & 10.2 & 3.13 & 11 \\
\hline
\end{tabular}

Source: Field survey (2018)

Interviews conducted with company's Directors/Owners revealed that construction site accidents have negative economic impacts on Nigerian construction companies. One of the interviewees made the following statements:

"Site accidents negatively impact on company's productivity and profitability"

"We spend so much on medical bills and insurance if accidents occur"

One of the owners of a small construction firm made this statement:

My firm was almost closed down last year due to carelessness of one plant operators who involved in fatal accident."

The costs of replacing the plant and compensation were so enormous on the company.'

The interviews result corroborated literature and questionnaire findings in that the WHO, 2010) reports on safework, stated that medical expenses incurred by developing countries annually due to poor site $\mathrm{H} \& \mathrm{~S}$ management are over $\$ 1000$ billion.

\subsection{Economic impacts of site accidents on the society}

The study questionnaire also examined the economic effects of construction accidents on the citizenry, through their impacts on the workers or their families. Table 2 showed the perception of respondents with regards to the extent in which stated accident variable factors exert economic pressure on workers or their families. Result from the findings show that each of the four stated accident variable factors had a mean score in excess of 3.00; and an average mean score of 3.42, thus indicating strong perception by the respondents that the stated accident variable factors impact on society through affected workers or their families. Study results also showed that 'decrease in family income' and 'increase in debts' ranked highest amongst the stated accident variable factors. 
Table 2: Economic impacts of site accidents on the society

\begin{tabular}{|c|c|c|c|c|c|c|c|c|}
\hline \multirow{3}{*}{ Statement of Accident Variable Factor } & \multirow{3}{*}{ 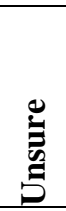 } & \multicolumn{5}{|c|}{ Response (\%) } & \multirow[b]{3}{*}{$\sum^{\infty}$} & \multirow{3}{*}{ 兰 } \\
\hline & & \multicolumn{5}{|c|}{$\begin{array}{l}\text { Minor impact... ........ Major } \\
\text { impact }\end{array}$} & & \\
\hline & & 1 & 2 & 3 & 4 & 5 & & \\
\hline Decrease in family income & 4.2 & 6.3 & 11.9 & 25.2 & 29.4 & 23.1 & 3.51 & 1 \\
\hline Increase in debts & 9.1 & 4.9 & 9.8 & 27.9 & 27.9 & 20.3 & 3.49 & 2 \\
\hline Decrease in family standard of living & 7.7 & 5.6 & 14.7 & 23.1 & 28.7 & 20.3 & 3.43 & 3 \\
\hline Children/dependants withdraw school & 1.4 & 4.4 & 12.1 & 21.1 & 30.3 & 21.2 & 3.42 & 4 \\
\hline
\end{tabular}

Source: Field survey (2018)

Interviews were conducted with affected workers or families to validity the questionnaire findings. One of the wives of the affected workers agreed that site accidents have negative impacts on the family life. She made the following statements.

"Since last two years my husband died as a result of collapsed on-going building project at Warri Central District (Delta State), my two children have dropped out of school because of there is no money to pay for their fees."

"The little business I was doing when my husband was working with the construction company has stopped". "I have borrowed so much from friends and relatives, but unable to pay."

The statements corroborated with literature finding in that, Mthalane et al. (2009) found out in South Africa that construction site accidents have social impacts on affected families such as decrease in family income and increase in debts. The decrease in family income as a result of death of the family provider through construction site accidents has direct negative social consequences on the society.

\subsection{Social impacts of construction site accidents on the construction company}

The extent, to which stated accident variable factors impact on Nigeria construction companies socially, is as shown in Table 3. Results from the study revealed that each of the five stated variable factors recorded a mean score above the 3.00 mid-score average and an aggregate mean score average of 3.41. This score is adjudged high, and indicates respondent's perception that the five stated variable factors socially impact on the construction companies to a considerable extent. The results further showed that the respondents ranked 'loss of customers' confidence, tarnished image, and loss of customer's satisfaction' highest in the list of construction accident variable factors.

Table 3: Social impacts of site accidents on the construction company

\begin{tabular}{|c|c|c|c|c|c|c|c|c|}
\hline \multirow{3}{*}{ Statement of Accident Variable Factor } & \multirow{3}{*}{ 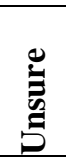 } & \multicolumn{5}{|c|}{ Response (\%) } & \multirow{3}{*}{$\sum^{\infty}$} & \multirow{3}{*}{ ت્ચ } \\
\hline & & \multicolumn{5}{|c|}{ Minor Impact..........Major Impact } & & \\
\hline & & 1 & 2 & 3 & 4 & 5 & & \\
\hline Loss of customers' confidence & 4.2 & 6.3 & 11.9 & 25.2 & 29.4 & 23.1 & 3.51 & 1 \\
\hline Tarnished image & 9.1 & 4.9 & 9.8 & 27.9 & 27.9 & 20.3 & 3.49 & 2 \\
\hline Loss of customers' satisfaction & 7.7 & 5.6 & 14.7 & 23.1 & 28.7 & 20.3 & 3.43 & 3 \\
\hline Loss of public confidence & 8.4 & 7.7 & 10.5 & 27.9 & 31.5 & 13.9 & 3.34 & 4 \\
\hline Low morale of workers & 6.3 & 5.6 & 11.9 & 40.6 & 12.7 & 13.9 & 3.27 & 5 \\
\hline
\end{tabular}

Source: Field survey (2018)

Interviews conducted with the owners/directors of construction companies supported the research findings. One of the Directors of a civil and road construction company interviewed attested that site fatalities have the potential to induce a serious crisis within the company and could lead to criminal proceedings and sometimes project closure. 
One of the managers interviewed stated that site accidents are devourers. The managers went further and stated:

"Fatal accidents tarnish company image that often leads to inability to obtain future jobs from prospective clients".

The interviewed results corroborated with literature findings in that, the WHO (2010) stated that site accidents are often associated with adverse media publicity that is capable of tarnishing company's image and loss of public confidence.

\subsection{Social impacts of site accidents on the society}

Table 4 shows the perception of respondents regarding the extent to which the stated construction accident variable factors impact on society socially. The results of the findings show that all the four stated accident variable factors had a mean score value in excess of 3.00; with an aggregate mean score value of 3.41. This was considered reasonably high; implying that respondents perceive the stated construction accident variable factors as having a social impact on society through the affected families. The findings also indicate that the respondents perceive that death of family bread winner, and decrease in quality of life as ranking highest on the list of stated accident variable factors.

The findings results corroborated with literature review in that, Spangenberg (2009) stated that site fatalities could create tensions within the organizations that are usually characterized with accusations and blames that may divert energies and resources away from the construction tasks at hand to accidents investigations. In addition, it was found from literature that site fatalities have the potential to induce a serious crisis within the company and could lead to criminal proceedings and sometimes project closure.

Table 4: Social impacts of site accidents on the society

\begin{tabular}{|c|c|c|c|c|c|c|c|c|}
\hline \multirow{3}{*}{ Statement of Accident Variable Factor } & \multirow{3}{*}{ 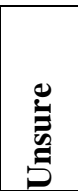 } & \multicolumn{5}{|c|}{ Response (\%) } & \multirow[b]{3}{*}{$\sum_{i}^{\infty}$} & \multirow[b]{3}{*}{ ש̈ } \\
\hline & & \multicolumn{5}{|c|}{ Minor Impact..............Major Impact } & & \\
\hline & & 1 & 2 & 3 & 4 & 5 & & \\
\hline Death of family bread winner & 4.2 & 6.3 & 11.9 & 25.2 & 30.4 & 23.1 & 3.51 & 1 \\
\hline Decrease in quality of life & 9.1 & 4.9 & 9.8 & 27.9 & 27.9 & 20.3 & 3.49 & 2 \\
\hline Family depression & 7.7 & 5.6 & 14.7 & 23.1 & 28.7 & 20.3 & 3.43 & 3 \\
\hline Loss of worker to the community & 6.3 & 4.2 & 11.1 & 24.5 & 26.1 & 19.4 & 3.41 & 4 \\
\hline
\end{tabular}

Source: Field survey (2018)

The interviewed results corroborated with literature findings in that, the (ILO, 2010) stated that construction site accidents have caused serious dearth of skilled and unskilled workforce in the construction industry.

One of the relatives of affected worker interviewed made the following statements:

"There is no amount of compensation paid to the family of a diseased worker can replace the life of a family bread winner".

"Since my senior brother lost one of his legs in site accident, the family has not been the same".

"There is a serious decrease in quality of life among his children"

The above statements corroborated literature findings and questionnaire survey results.

\section{CONCLUSIONS AND RECOMMENDATIONS}

Work-related accidents and incidents among Nigerian construction companies remain one of the burning issues in the country. Site accidents have serious negative impacts on companies' productivity and annual balance sheets. The pains and sufferings borne by workers, their families and the economic impacts of site accidents to national 
economy is a serious concern to all. In addition, the negative social impacts of work-related accidents particularly to families who lost their bread winners to construction site accidents are unquantifiable. Children dropped out of school and debts increases among the families who lost their dear one or permanently deformed as a result of site accidents. Construction site accidents tarnishes company's image thereby making it difficult to obtain future job from prospective clients. In the light of the foregoing this research therefore recommends as follows:

1. An active collaboration with relevant safety organizations, institutions, including government agencies for the establishment of a uniform, credible safety management standards and safe working practices in the construction industry.

2. A strict enforcement of Health \&Safety laws, regulations at all levels, and the sanction of construction companies that violate $H \& S$ legislation.

3. The demonstration of a visible leadership in all matters that concerns workers' health, safety and wellbeing on construction sites.

4. Commitment of the management of construction companies to the safety management function in all its ramifications and entrenching same as a value, as they do in other businesses.

5. Consideration of workers $H \& S$ training and protective equipment provision as a critical imperative during tender prequalification and general pre-contract practice.

\section{REFERENCES}

Akinwale, A.A. \& Olusanya, O. A. (2016) Implication of occupational health and safety intelligence in Nigeria, Journal of Global Care Systems, Vol.6, No.1, (23-45). View at Google Scholar.

Asanka, W.A, \& Ranasinghe (2015) Study on the impact of accidents in construction projects, In the proceedings of the 6th International conference on Structural Engineering and Construction Management, Kandy, Sri Lanka, 11th- 13th December, 2015, pp58-67.

Brauer, L.R. (2006) Safety and health for engineers, 2nd Ed., New Jersey: Wiley-Interscience.

Conchie, S.M., Taylor, P.J. \& Charlton, A. (2011) Trust and distrust in leadership: mirror reflections? Safety Science 49(1), 1208-1214.

Danity, A.R.J. (2008) Methodological pluralism in construction management research, In: Knight, A. and Roddock, L. (Eds). Advanced research methods in the built environment, oxford: willey-Blackwell, pp.13.

Flin, R. \& Yule, S. (2003) Leading for safety; industrial experience. Quality and Safety Health Care, 3(20, 45-51.

Fewings, P. (2010) Working at Height and Formwork, In McAleenan, P. and Oloke, D. (Eds). ICE Manual of Health and Safety, London: Thomas Telford, 165-179.

Gambatese, J.A. (2008) Research issues in Prevention through Design. Journal of Safety Research, 39 (2), pp. 153-156.

Goetsch, D.L (2014).,Construction safety and health, 3nd Ed., New Jersey: Prentice Hall.

Hughes, P. \& Ferrett, E. D. (2010) Introduction to Health and Safety in Construction, Butterworth-Heinemann, Elsevier Linacre House, Jordan Hill Oxford 0X2 8DP, UK.

Health and Safety Executive (2011) Reducing error and influencing behaviour: HSG-48. UK.

Health, Safety and Executive (HSE0 (2010) Managing H\&S in construction, construction (Design and Management) Regulations 2007, Approved, Code of PracticeL144 HSE Books 2007 ISBN: 071766223 4

Hinze, J. W. (2006) Construction safety, New Jersey: Prentice-Hall. 
International Labour Organisation (2011), ILO standard on occupational safety and health promoting safe and healthy working environment: Geneva, ILO.

International Labor office (ILO)(2011), ILO Introductory report: global trends and challenges on occupational safety and health “, in XIX World Congress on Safety and Health at Work, Istanbul, Turkey, pp. 11-15.

Kheni, N. A. (2008) Impact of Health and Safety Performance on Small and Medium Sized Construction Businesses in Ghana, (PhD): Loughborough University, UK.

Leedy, P.D. \& Ormrod, J, E. 2010) Practical research: Planning and design, 8th edition, Upper saddle River, New Jersey: Pearson.

Leigh, J. (2011), 'Economic burden of occupational injury and illness in the United States' Milbank Q, Vol.89, No 4; pp 728-772.

Lutchman, C., Maharaj, R. \&Ghanem, W. (2012) Safety management: a comprehensive approach to developing a sustainable system,1st ed., New Jersey:CRC Press.

National Occupational Safety and Information Centre (NOSHIC) Republic of Nigeria, 2006) Report of occupational safety and health, Abuja: NOSHIC.

Musonda, I., Pretorius, J. \&Haupt, T.C. (2012) Assuring health and safety performance on construction projects: clients' role and Influence, ActaStructilla, 19(1), 71-105.

Mthalane, D. Othman, A.A.E. \& Pearl, R.G. (2008) The economic and social impacts of site accidents on the South African society, Journal of South African Institution of Civil Engineering. 77-87.

McAleenan, D. (2010) Controlling Exposure to Biological Hazards, In McAleenan, P. and Oloke, D. (Eds). ICE Manual of Health and Safety, London: Thomas Telford, 100-101.

Okoye, P.U., Okoilr, K.C. \& Ngwu, C. (2017) Multilevel safety intervention implementation strategies for Nigeria construction, Journal Construction Engineering, Vol. 2017 (2), 13-32.

Olatunji, O.A., Sher, W. \& Gu, N. (2011) Building information and quantity surveying practice. Emirates Journal for Engineering Research, 15(1), 67-70.

Oloke, D. (2010) Controlling Exposure to Biological Hazards, In McAleenan, P. and Oloke, D. (Eds.). ICE Manual of Health and Safety, London: Thomas Telford, 29-37.

Okorie, V. N. \& Musonda, I. (2018) An investigation on supervisor's ability and competency to conduct construction site health and safety induction training in Nigeria, International Journal of Construction Management, DOI: 10.1080/15623599.2018.1531808.

Okorie, V.N. \& Aigbavboa, C. (2016) The economic and social impacts of site accidents on medium and small sized construction companies in Nigeria. In Proceedings of 2nd International Conference on Infrastructural Development in Africa: Johannesburg, edited by C, Aigbavboa and D.Thelwa (ICIDA), 154-163).

Spangenberg, S. (2009) An Injury Risk Model for Large Construction Projects, Risk Management an International Journal, 11 (2), 111-129.

World Health Organisation (WHO, 2010), World Health Report 2010, Geneva: London.

Wikipedia (2019) "Developing country" (online) Available: https:Ilen.wikipedia.org/wiki/Developing country\# Factors - stimulating - growth. (Accessed: 28 - Jan 2019). 